\title{
TRIPLE BOTTOM LINE DAN NILAI PERUSAHAAN, GROSS PROFIT MARGIN SEBAGAI INDIKATOR EKONOMI
}

\author{
Sri Wahjuni Latifah \\ sriwahjuni@umm.ac.id \\ Universitas Muhammadiyah Malang
}

\begin{abstract}
This research was conducted with the first objective of testing the effect of Triple Bottom Line performance on the company's value. The second objective is to test whether the Gross Profit Margin variable can be an indicator of economic performance variables and affect the company's value. This research was conducted on companies that go public on the IDX and the research sample is manufacturing companies in the basic and chemical industry sectors that have reported their performance in the 2018 Sustainability Report. The Triple Bottom Line performance variable is measured by the GRI G-4 index while the company value is measured by Tobin's value. Q. Data obtained by documentation techniques. Data analysis using descriptive and quantitative approaches. The hypothesis in this study was tested using Smart PLS analysis. The results showed that the triple bottom line performance had a positive effect on firm value. Likewise, the gross profit margin can be a measure of economic performance in the Triple Bottom Line and has a positive effect on firm value. The triple bottom line is formed by indicators of economic performance, environmental performance and social performance.
\end{abstract}

Key words: triple bottom line; performance; gross profit margin

\begin{abstract}
ABSTRAK
Penelitian ini dilakukan dengan tujuan pertama menguji pengaruh kinerja Triple Bottom Line terhadap nilai perusahaan. Tujuan kedua menguji apakah variabel Gross Profit Margin dapat menjadi indikator variabel kinerja ekonomi dan berpengaruh terhadap nilai perusahaan. Penelitian ini dilakukan pada Perusahaan yang Go Public di BEI dan sampel penelitiannya adalah perusahaan manufaktur sektor industri dasar dan kimia yang telah melaporkan kinerjanya pada Laporan Sustainbility tahun 2018. Variabel kinerja Triple Bottom Line di ukur dengan indeks GRI G-4 sedangkan nilai perusahaan diukur dengan nilai Tobin's $Q$. Data diperoleh dengan teknik dokumentasi. Analisis data dengan pendekatan deskriptif dan kuantitatif. Selanjutnya hipotesis diuji dengan analisis Smart PLS. Hasil penelitian menunjukkan bahwa kinerja triple bottom line berpengaruh positif pada nilai perusahaan. Demikian juga bahwa gross profit margin dapat menjadi ukuran kinerja ekonomi dalam Triple Bottom Line dan berpengaruh positif pada nilai perusahaan. Bahwa Triple bottom Line dibentuk oleh indikator kinerja ekonomi, kinerja lingkungan dan kinerja sosial.
\end{abstract}

Kata kunci: kinerja; triple bottom line; gross profit margin

\section{PENDAHULUAN}

Pada awalnya tujuan didirikannya perusahaan berupa tujuan jangka pendek yang hanya berorientasi laba. Untuk mencapai tujuan jangka pendek perusahaan berupaya meraih keuntungan sebesar besarnya sehingga memicu explorasi akan sumber daya alam menjadi semakin tinggi. Bahkan terkadang tanpa memperhatikan lingkungan sekitar baik keseimbangan lingkungan, karyawan, ekosistem maupun perusahaan itu sendiri. Namun sekarang tujuan per usahaan sudah bergeser mengutamakan tujuan jangka panjang yaitu keberlanjutan atau sustainbility.

Sustainbility atau berkelanjutan adalah strategi manajemen dengan pendekatan kinerja perusahaan secara berkelanjutan 
dalam berbagai aspek yang meliputi: aspek ekonomi, lingkungan, dan sosial, termasuk potensi dalam menciptakan nilai perusahaan. Pelaporan kinerja ekonomi, lingkungan dan sosial dilakukan dalam sebuah laporan laporan tahunan atau laporan yang lebih lengkap yang disebut Sustainbility Report. Laporan Sustainbility memberikan informasi akuntabilitas, responsibilitas, dan transparansi sebuah perusahaan kepada investor dan stakeholder lainnya. Pengelolaan perusahaan yang baik akan melakukan pengungkapan informasi wajib maupun infor masi sukarela sehingga hal ini akan berpengaruh pada nilai perusahaan. Hal ini disebabkan pengungkapan informasi terbukti memberi manfaat positif bagi investor dalam membantu keputusan investasi, sehingga nilai perusahaan akan naik karena investor membeli saham perusahaan tersebut (Haposro, 2009).

Diberlakukannya Undang-Undang Nomor 32 Tahun 2009 yang tentang" Perseroan yang menjalankan kegiatan usahanya di bidang dan atau berkaitan dengan sumber daya alam wajib melaksanakan tanggung jawab sosial dan lingkungan".Peraturan ini dilengkapi dengan peraturan UU no. 40 tahun 2007 Pasal 66 tentang tanggungjawab sosial dan lingkungan wajib didiinformasi dalam laporan tahunan. Masyarakat percaya bahwa adanya efek negatif perusahaan saat menjalankan operasinya sehingga manajemen dituntut tidak hanya berfokus memaksimalkan laba, namun memberikan kontribusi yang baik dan positif pada lingkungan.

Hal ini menjadi keharusan sebuah perusahaan melakukan aktivitas dengan bertanggung jawab pada lingkungan maupun sosial yang dikenal dengan CSR (Corporate Social Responsibility). Perusahaan diwajibkan untuk tidak hanya menerapkan konsep single bottom line, yaitu tidak hanya berorientasi pada tujuan profit tetapi perusahaan di tuntut untuk menerapkan Triple bottom line yang merupakan konsep menguntungkan perusahaan dan menguntungkan manusia dan lingkungan sekitar. Konsep Triple Bottom Line telah dikembangkan oleh John Elkington pada tahun 1999 yang dikenal dengan "Canibals with Forks: the Triple Bottom Line of 21st Century Business" yang memjelaskan pentingnya profit, planet dan people.(Żak, 2015). Usaha yang sukses dapat diketahui dari informasi akuntansi yang melaporkan profit serta memenuhi tanggungjawab pada lingkungan (planet) dan memenuhi tanggungjawab pada sosial (people). Pendekatan Triple Bottom Line menjelaskan bahwa perusahaan dipengaruhi faktor internal dan eksternal (Jackson et al., 2011). Secara istilah konsep Triple Bottom Line dianggap sama dengan Corporate Social Responsibility (CSR). Konsep triple bottom line (profit, people, planet) merupakan elemen utama membangun sustainability development (Latifah, 2016)

Salah satu pendukung stakeholders oriented adalah perusahaan harus menjalankan strategi corporate social responsibility (CSR). Maka pengungkapan corporate social responsibility dianggap penting terhadap keberlangsungan suatu perusahaaan. CSR yang ada dapat digunakan sebagai media untuk mendapatkan legitimacy dari para pemangku kepentingan (stakeholders), hal ini dikarenakan peusahaan tidak bisa beroperasi dan bertahan tanpa bantuan dari para stakeholdersnya.

Selain itu, pengungkapan CSR dalam suatu perusahaan dapat dijadikan salah satu cara untuk memenuhi hak-hak para stakeholders dalam memperoleh informasi yang berkaitan langsung dengan kegiatan perusahaan, jika perusahaan terus berusaha memperhatikan kepentingan stakeholders maka perusahaan akan mendapatkan signal yang akan diberikan kepada publik bahwa perusahaan memiliki prospek yang panjang dan akan terciptanya sustainability development (Laksmitaningrum dan Purwanto, 2013).

Perusahaan dapat dikatakan baik apabila dapat meningkatkan nilai perusahaannya untuk eksistensi jangka panjang. Nilai 
perusahaan sering dikaitkan dengan harga saham, semakin tinggi harga saham, semakin tinggi pula nilai perusahaan, sehingga akan mempengaruhi investor dalam pengambilan keputusan investasi (Putri et al., 2018). Pengambilan keputusan investasi tidak hanya berfokus pada informasi finansial saja tetapi juga diperlukannya pengungkapan informasi non-keuangan yang juga dinilai sangat penting dalam pertimbangan pengambilan keputusan investasi (Devi et al., 2017).

Maka nilai perusahaan adalah hal yang sangat penting bagi perusahaan dalam membantu pendanaan perusahaan serta menggambarkan kinerja yang dapat memberikan informasi untuk investor dalam mengevaluasi perusahaan dalam keputusan investasi. Beberapa informasi penting sebagai dasar penilaian investor dalam mengestimasi nilai perusahaan dapat dilihat return. Tingkat pengembalian (return) investor dapat diprediksi dari laba perusahaannya. Nilai perusahaan pada perusahaan yang sahamnya diperdagangkan pada publik dan relevan untuk pengambilan keputusan adalah berkaitan dengan nilai kapitalisasi pasarnya. Penilaian ini dikenal dengan nilai pasar Tobins"q. Tobin'Q menunjukkan proforma manajemen dalam mengelola aset perusahaan dan menunjukkan peluang investasi yang dimiliki perusahaan. Tingginya nilai perusahaan memberikan informasi bahwa perusahaan mampu memaksimalkan nilai perusahaan yang dimiliki serta memberikan kepuasan pemegang saham. Dengan demikian nilai perusahan penting diperhatikan oleh calon investor. Semakin tinngi nilai perusahaan maka semakin tinggi kemakmuran para pemegang saham (Lang et al., 1989).

Salah satu ukuran profitabilitas perusahaan adalah Gross Profit Margin (GPM). GPM merupakan kelebihan laba kotor terhadap penjualan. GPM juga mengukur seberapa efisien perusahaan menggunakan bahan baku, tenaga kerja langsung, dan peralatan untuk menghasilkan produk dan jasa yang akan dijual dan menghasilkan keuntungan. GPM ini memberikan informasi yang sebenarnya kepada investor tentang kinerja keuangan yang sesungguhnya dari sebuah perusahaan. Untuk itu pengungkapan corporate social responsibility pada perusahaan diharapkan akan berdampak baik pada citra perusahaan sehingga akan meningkatkan nilai perusahaan.

Berbagai riset tentang CSR dan nilai perusahaan sudah banyak dilakukan. Diantaranya (Raharjo dan Djanuarti, 2014) menemukan bahwa CSR berpengaruh pada nilai perusahaan pertambangan yang diukur dengan nilai Tobin,s Q. Penelitian ini juga menemukan bahwa indeks pengungkapan CSR berdasar GRI 2008-2011 pada perusahaan pertambangan di Indonesaia adalah rendah yaitu $10 \%$. Demikian juga penelitian yang dilakukan oleh (Latifah dan Luhur, 2017) menemukan bahwa Sustainbility Report berpengaruh terhadap nilai perusahaan.

Berbeda dengan penelitian (Agustine, 2014) mengungkapkan bahwa pengungkapan corporate social responsibility tidak berpengaruh terhadap nilai perusahaan. Demikian juga penelitian dengan populasi perusahaan manufaktur yang terdaftar di BEI tahun 2015-2017 yang mengungkapkan corporate social responsibility telah dilakukan oleh (Sutriningsih et al., 2019). Berdasar analisis jalur temuan penelitian menunjukkan bahwa kinerja keuangan (ROE) tidak dapat berfungsi sebagai variabel intervening dalam pengaruh CSR terhadap nilai perusahaan pada perusahaan manufaktur di BEI periode 2015-2017.

Penelitian ini penting dilakukan karena berbagai hasil penelitian tentang pengaruh CSR terhadap nilai perusahaan menujukkan hasil yang berbeda-beda. Penelitian ini dilakukan untuk menguji kinerja triple bottom line perusahaan yang diukur dengan kinerja ekonomi, kinerja lingkungan dan kinerja sosial terhadap nilai perusahaan yang diukur dengan nilai Tobin's Q. Sebagaimana diketahui bahwa selama ini kinerja ekonomi dalam triple bottom line hanya mengukur kinerja berdasar aktivitas ekonomi, lingkungan dan sosial dan tidak 
mengukur langsung kinerja keuangan berkaitan dengan kemampuan perusahaan dalam menghasilkan keuntungan berdasar efisiensi pengunaan bahan dan tenaga kerja. Penelitian ini bertujuan menguji apakah kinerja Triple Bottom Line yang meliputi: kinerja ekonomi, kinerja lingkungan dan kinerja sosial berpengaruh pada nilai perusahaan. Selanjutnya untuk menguji apakah kemampuan perusahaan dalam menghasilkan profit (GPM) merupakan indikator variabel kinerja ekonomi dalam menentukan Nilai Perusahaan

\section{TINJAUAN TEORETIS Triple Bottomline}

Penelitian yang dilakukan Aulia dan Kartawijaya (2011) tentang analisis pengungkapan Triple Bottom Line dan faktor yang mempengaruhinya (Lintas Negara Indonesia dan Jepang). Ditemukan bahwa perusahaan di Jepang mengungkapkan kinerja lingkungan lebih tinggi daripada negara Indonesia. Demikian juga penelitian tentang implementasi Triple Bottom Line di Indonesia oleh Nurfajriyah (2011). Tujuan penelitian tersebut mengidentifikasi program CSR PT. Pertamina (persero) yang sudah berjalan dan bagaimanakah implementasi konsep triple bottom line dalam pelaksanaan aktivitas CSR. Hasil penelitian menemukan kegiatankegiatan CSR PT. Pertamina (persero) periode 2007-2009 telah memenuhi konsep triple bottom line terdiri dari aktifitas berkaitan profit, people, dan planet. Aktivitas tanggungjawab bidang ekonomi (profit) PT. Pertamina (persero) meliputi laba dan produk-produk. Sedangkan tanggungjawab lingkungan (planet) terdiri dari programprogram berkaitan penyelamatan dan kelestarian lingkungan. Selanjutnya tanggungjawab sosial (people) meliputi aktivitas CSR bidang pendidikan, kesehatan, program kemitraan serta infrastruktur dan bencana.

\section{Global Reporting Initiative}

Global Reporting Initiative (GRI) merupakan sebuah organisasi nirlaba yang mempromosikan sustainbility. GRI mengeluarkan standar yang paling lazim sebgai pedoman pelaporan keberlanjutan, pelaporan lingkungan sosial pemerintahan, pelaporan Triple Bottom Line (TBL), dan pelaporan tanggungjawab sosial (CSR). GRI membuat pelaporan keberlanjutan untuk seluruh organisasi.

Pedoman GRI digunakan oleh semua organisasi lebih 3.000 organisasi dan 60 negara menggunakan pedoman untuk menghasilkan laporan keberlanjutan. Pedoman GRI berlaku untuk bisnis, layanan publik, perusahaan-perusahaan kecil, LSM, dan industri lainnya. GRI mengharmonisasi standar pelaporan lingkungan termasuk audit lingkungan. GRI mendorong perusahaan melaporkan kinerja lingkungan mereka dengan menggunakan kriteria tertentu.

Definisi sustainability report dalam GRI adalah pengukuran, pengungkapan dan akuntabilitas kinerja organisasi untuk mencapai tujuan berkelanjutan, dilaporkan kepada stakeholders. Sustainability report merupakan laporan yang dikeluarkan oleh perusahaan terdiri dari 3 aspek yaitu ekonomi, sosial, lingkungan. Pengungkapan sustainability report di Indonesia pada tahun 2016 bersifat voluntary, sehingga masih sedikit perusahaan menerbitkan laporan keberlanjutan. Dengan sustainability report dapat memberikan gambaran kinerja berkelanjutan sebuah perusahaan (Anindita, 2014).

\section{Teori Stakeholders}

Teori stakeholder mengasumsikan eksistensi sebuah perusahaan memerlukan dukungan dengan stakeholder, sehingga kegiatan perusahaan harus mempertimbangkan kepentingan stakeholder. Pengungkapan sosial dan lingkungan dipandang sebagai diskusi perusahaan dengan stakeholders (Januarti dan Apriyanti, 2005). Organisasi memilih menanggapi tuntutan stakeholders, yaitu semua pihak dalam lingkungan baik dalam organisasi ataupun luar organisasi yang terkena dampak keputusan organisasi. Menurut teori ini bahwa organisasi berusaha memenuhi tuntutan lingkungan dari 
stakeholders (Robbin dan Coulter, 1999). Teori lain yang berdekatan dengan teori Stakeholders adalah yang dikenal Good management theor. Good management theory berpendapat bahwa kinerja perusahaan secara keseluruhan akan meningkat apabila kebutuhan berbagai pemangku kepentingan ditangani (Waddock dan Graves, 1997). Teori di mana suatu perusahaan mendapat reputasi baik dari stakeholders seiring dengan kinerja sosial yang dilakukan perusahaan. Hal ini akan membuat perusahaan lebih mudah untuk mendapatkan posisi keuangan yang baik pula, sehingga kinerja sosial perusahaan merupakan hal yang perlu diperhatikan terlebih dahulu dibandingkan dengan kinerja keuangan perusahaan (Utari, 2014).

\section{Nilai Perusahaan}

Nilai perusahaan merupakan persepsi investor terhadap tingkat keberhasilan suatu perusahaan mengelola sumber daya yang tercermin pada harga saham (Rahayu dan Sari, 2018). Karena nilai perusahaan merupakan salah satu faktor yang diperhatikan oleh para calon investor dalam menentukan keberhasilan suatu perusahaan dalam kinerjanya adalah dengan melihat dari nilai perusahaan tersebut (Septariani, 2017). Salah satu aspek yang bisa dijadikan sebagai komponen dalam menilai baiknya suatu nilai perusahaan adalah dengan melihat harga saham dari perusahaan itu. Sehingga dapat dikatakan bahwa nilai perusahaan adalah saham yang dimiliki oleh suatu perusahaan yang diterbitkan dalam pasar modal yang bertujuan menarik minat investor untuk membeli saham perusahaan tersebut dengan harga yang sudah ditetapkan dan harus dibayarkan apabila pihak investor ingin memiliki perusahaan tersebut. Nilai perusahaan juga dapat dilihat dari kemampuan sebuah perusahaan membayar dividen. Jika perusahaan memperoleh laba tinggi, maka kemampuan perusahaan akan membayarkan dividen juga tinggi, sebaliknya seperti itu. Dengan dividen yang besar akan meningkatkan nilai perusahaan (Harjito dan Martono, 2005).
Tingginya nilai perusahaan dapat memberikan gambaran perusahaan yang artinya perusahaan mampu memaksimalkan nilai perusahaan yang dimiliki oleh perusahaan tersebut dan dapat memberikan kepuasan terhadap pemegang saham. Oleh karena itu nilai perusahan merupakan hal yang sangat penting untuk diperhatikan oleh para calon investor. Semakin tinngi nilai perusahaan maka akan semakin tinggi juga kepuasan serta kemakmuran yang dirasakan oleh para pemegang saham.

Brigham dan Houston (2010) menyatakan nilai perusahaan sebagai nilai pasar karena peningkatan harga saham yang maksimum dapat memberikan kemakmuran kepada pemegang saham. Untuk itu perusahaan berusaha membuat kebijakan untuk peningkatan kesejahteraan pemegang saham dengan mengoptimalkan nilai perusahaan.

Suatu perusahaan dikatakan memiliki nilai perusahaan yang baik jika kinerja perusahaan juga baik. Nilai perusahaan dapat tercermin dari harga sahamnya. Apabila harga perusahaannya tinggi, maka dapat dikatakan nilai perusahaannya juga baik.

Perusahaan yang memiliki tanggung jawab sosial yang baik akan mendapatkan apresiasi positif dari stakeholder, sehingga perusahaan dapat meningkatkan penjualan dan mengurangi biaya yang berujung pada meningkatnya profit perusahaan (Dean, 1998); (Eduardus dan Juniarti, 2016). Selain itu, perusahaan juga akan mendapat banyak keuntungan seperti kesetiaan pelanggan, serta kepercayaan dari kreditor dan investor. Hal ini akan memicu keuangan perusahaan menjadi lebih baik sehingga laba perusahaan meningkat dan akan diikuti oleh kenaikan ROA perusahaan di tahun berikutnya (Husnan dan Pamudji, 2013). Indikatorindikator nilai perusahaan diantaranya adalah: PER (Price Earning Ratio), PBV (Price Book Value) dan Tobin's Q. PER adalah salah ukuran nilai pasar perusahaan yaitu rasio yang mengukur seberapa besar perbandingan antara harga saham perusahaan terhadap laba. PER mengukur harga yang 
dibayarkan oleh investor untuk setiap dolar laba yang diperoleh perusahaan (Ross et al., 2015). Manfaat price earning ratio adalah untuk melihat bagaimana pasar menghargai kinerja perusahaan yang dicerminkan oleh earning per share nya. Price earning ratio menunjukkan hubungan antara pasar saham biasa dengan earning per share.

Sedangkan PBV adalah mengukur nilai yang diberikan pasar keuangan kepada manajemen dan organisasi perusahaan sebagai sebuah perusahaan yang terus tumbuh (Brigham dan Houston, 2010). Komponen penting lain yang harus diperhatikan dalam analisis kondisi perusahaan adalah Price to Book Value (PBV) yang merupakan salah satu variabel yang dipertimbangkan seorang investor dalam menentukan saham mana PER = Harga pasar perlembar saham Laba perlembar saham yang akan dibeli. Untuk perusahaan-perusahaan yang berjalan dengan baik, umumnya rasio ini mencapai diatas satu, yang menunjukkan bahwa nilai pasar saham lebih besar dari nilai bukunya.

Tobin's Q ditemukan oleh seorang peraih Nobel dari Amerika Serikat yaitu James Tobin. Tobin's Q dapat dirumuskan sebagai perbandingan nilai pasar aset dengan perkiraan jumlah uang yang harus dikeluarkan untuk mengganti seluruh aset tersebut pada saat ini. Rasio Tobin's Q adalah rasio nilai pasar aset perusahaan dibagi dengan biaya penggantinya (Ross et al., 2015). Nilai perusahaan merupakan hal yang sangat penting bagi stakeholders karena nilai perusahaan yang sangat tinggi akan diikuti oleh tingginya kemakmuran bagi pemegang saham. Semakin tinggi harga saham maka semakin meningkatnya nilai perusahaan yang akan menunjukkan prospek perusahaan di masa yang akan datang. Peningkatan nilai perusahaan dapat menggambarkan kesejahteraan dan kemakmuran pemilik perusahaan, sehingga pemilik perusahaan akan mendorong para manajer bekerja lebih keras lagi dengan menggunakan insentif untuk memaksimalkan nilai perusahaan. Meningkatnya nilai per- usahaan merupakan sebuah prestasi yang sesuai dengan keinginan para pemiliknya, maka kesejahteraan para pemilik perusahaan juga akan meningkat. Nilai perusahaan dapat dikatakan baik apabila memiliki nilai lebih dari $1(>1)$

Berkaitan dengan nilai perusahaan ada beberapa faktor yang mempengaruhi Nilai Perusahaan(Mutammimah, 2020). Hasil penelitian pada perusahaan manufaktur yang terdafar di BEI tahun 2013-2017 tersebut menunjukkan bahwa Kebijakan hutang dan profitabilitas berpengaruh pada nilai perusahaan, namun kepemilikan manajerial, Kebijakan Dividen, Ukuran Perusahaan, Pertumbuhan Perusahaan tidak berpengaruh signifikan pada nilai perusahaan. Hasil penelitian tentang nilai perusahaan di Indonesia menemukan bahwa faktor -faktor yang mempengaruhi nilai perusahaan adalah Dividend Payout dan ukuran perusahaan. Sedangkan leverage dan profitabilitas tidak berpengaruh pada nilai perusahaan (Gusaptono, 2010).

Kebijakan dividen merupakan keputusan apakah laba yang diperoleh perusahaan akan dibagikan kepada pemegang saham sebagai dividen atau akan ditahan dalam bentuk laba ditahan guna pembiayaan investasi di masa datang. Pembayaran dividen yang semakin meningkat menunjukkan prospek perusahaan semakin bagus sehingga investor akan tertarik untuk membeli saham dan nilai perusahaan akan meningkat.

Profitabilitas merupakan tingkat keuntungan bersih yang dapat diperoleh sebuah perusahaan dari kegiatan opersasionalnya yangmana keuntungan tersebut ada yang dibagikan kepada pihak pemegang saham dalam bentuk dividen, dan bisa juga keuntungan tersebut disimpan dan digunakan untuk meningkatkan kinerja kegiatan operasional. Profitabilitas mengukur seberapa efisien suatu perusahaan dalam memanfaatkan asetnya dan mengelola kegiatan operasinya (Ross et al., 2015). Profitabilitas dapat diukur dengan profit margin, gross 
profit margin, return on aset dan return on equity.

Pertanggung jawaban sosial perusahaan (Corporate Social) merupakan mekanisme bagi suatu organisasi untuk secara sukarela mengintegrasikan perhatian terhadap lingkungan dan sosial ke dalam operasinya dan interaksinya dengan stakeholders.Corporate Social Responsibility (CSR) menjadi salah satu factor yang mempengaruhi nilai perusahaan karena salah satu dasar pemikiran yang melandasi etika bisnis sebuah perusahaan. Semakin banyak perusahaan mengungkapkan CSR dalam laporan tahunan, maka semakin baik pula nilai perusahaan di mata investor, kreditor, ataupun masyarakat.

\section{Gross Profit Margin}

Kemampuan perusahaan dalm menghasilkan laba dkenal dengan istilah profitabilitas. Profitabilitas dapat diukur dengan Gross Profit Margin (GPM). Gross Profit Margin (GPM) merupakan kelebihan laba kotor terhadap penjualan. GPM juga mengukur seberapa efisien perusahaan menggunakan bahan baku, tenaga kerja langsung serta peralatan untuk menghasilkan produk dan jasa yang akan dijual dan menghasilkan keuntungan. GPM ini memberikan informasi yang sebenarnya kepada investor tentang kinerja keuangan yang sesungguhnya dari sebuah perusahaan.

\section{Hipotesis Penelitian}

Penelitian Dahlia dan Siregar (2008) pada tujuh puluh tujuh perusahaan yang listed di BEI terbukti CSR berpengaruh pada kinerja keuangan. Di Indonesia rata-rata perusahaan mengungkapkan CSR adalah rendah. Hal ini dibuktikkan (Yapto et al., 2013) bahwa pengungkapann CSR pada perusahaan manufaktur pada tahun 20102011 rata-rata sebesar 27,10. Demikian juga Nurlela dan Islahudin (2007) meneliti pada 340 perusahaan non keuangan di BEI menemukan bahwa CSR berpengaruh positif pada nilai perusahaan.

Penelitian lain yang menghasilkan temuan yang sama dilakukan oleh Astuti et al. (2018). Penelitian dilaksanakan pada perusahaan yang menerbitkan sustainability report dan yang terdaftar di Bursa Efek Indonesia (BEI) tahun 2012-2016. Hasil penelitian menunjukkan bahwa pengungkapan corporate social responsibility berpengaruh positif dan signifikan terhadap nilai perusahaan. Hal ini berarti bahwa tinggi rendahnya indeks sustainability report berdampak terhadap nilai perusahaan.

Penelitian pengaruh pengungkapan CSR terhadap nilai perusahaan juga dilakukan oleh Schadewitz dan Niskala (2020) di Finlandia. Penelitian tersebut menggunakan 276 sampel perusahaan go publik di Finlandia dari tahun 2002 sampai 2005. Hasil menunjukkan bahwa pengungkapan CSR berpengaruh positif terhadap nilai perusahaan.

Nilai perusahaan akan meningkat dan dipandang baik jika perusahaan memperhatikan kesejahteraan para stakeholdernya bukan hanya memperhatikan kepentingan pemilik atau shareholder semata. Hal ini dikarenakan perusahaan tidak akan dapat mencapai tujuan dengan baik jika tidak didukung oleh stakeholdernya. Pada saat perusahaan mengungkapkan corporate social responsibility juga dapat meningkatkan kepercayaan kepada para stakeholdernya. Kepercayaan ini dapat ditunjukkan dengan diterimanya produk-produk perusahaan yang akan meningkatkan laba dimana saat laba naik maka dapat berpengaruh terhadap nilai perusahaan.

Berdasar urian di atas hipotesis penelitian ini:

$\mathrm{H}_{1}$ : Kinerja Triple Bottom Line dengan indikator kinerja ekonomi, kinerja lingkungan dan kinerja sosial berpengaruh terhadap nilai perusahaan.

Kinerja perusahaan dapat diukur dengan ukuran keuangan seperti profitabilitas dan non keuangan seperti Triple Bottom Line atau CSR. Profitabilitas yang tinggi akan berdampak pada nilai perusahaan semakin tinggi karena memberikan tingkat imbal hasil yang tinggi untuk investor. Penelitian tentang profitabilitas 
dan kinerja lingkungan terbukti dapat berpengaruh pada nilai perusahaan yang diukur dengan Tobin'Q. Bahwa kinerja lingkungan berdasar ISO 26000 yang dimoderasi oleh profitabilitas berpengaruh pada nilai perusahaan yang termasuk dalam Indeks LQ-45 (Latifah, 2012). Maka hipotesis kedua penelitian ini adalah:

$\mathrm{H}_{2}$ : Kinerja Triple Bottom Line dengan Gross Profit margin sebagai ukuran kinerja ekonomi berpengaruh terhadap nilai perusahaan.

\section{METODE PENELITIAN}

Penelitian ini dilakukan pada perusahaan industri dasar dan kimia yang mempublikasikan Laporan Sustainbility Report dan terdaftar di Bursa efek Indonesia pada tahun 2018. Tehnik sampling penelitian menggunakan purposive sampling, dengan kriteria bahwa perusahaan Manufaktur Sektor Industri dasar dan kimia tersebut terdaftar di BEI tahun 2018, Perusahaan yang menerbitkan Annual Report atau laporan tahunan yang lengkap, perusahaan tidak mengalami kerugian pada tahun 2018 dan Laporan keuangan dinyatakan dalam rupiah

Perolehan data dilakukan dengan cara mendownload web Idx. Variabel penelitian meliputi variable independen yang terdiri dari kinerja profit diukur dengan indikator ekonomi GRI G-4 sejumlah 9 indikator, kinerja planet diukur dengan GRI G-4 index kategori lingkungan terdiri 34 indikator dan kinerja people diukur dengan GRI index kategori sosial 48 indikator. Pengukuran kinerja Triple Bottom Line menggunakan CSRIndeks, yaitu jumlah yang diungkapkan dibanding total pengungkapan yang seharusnya dengan rumus: $\operatorname{CSRI}_{\mathrm{j}}=\frac{\sum x i j}{n j}$, dengan penjelasan CSRIj = Indikator pengungkapan corporate social responsibility, $\sum x \mathrm{xij}=$ jumlah item diungkapkan perusahaan, $\mathrm{nj}=$ jumlah keseluruhan item, nj $\leq 91$. Sebelumnya diukur dengan indikator GRI yaitu GRI G-4 bahwa item yang diungkapkan perusahaan diberi nilai satu (1) dan nilai nol (0) jika tidak diungkapkan. Selanjutnya indi- kator variable ekonomi yang berikutnya adalah Gross Profit Margin yang diukur dengan laba kotor dibanding penjualan. Sedangkan variabel dependennya adalah nilai perusahaan diukur dengan Tobin's Q. Nilai Tobin's Q menunjukkan estimasi dari pasar keuangan saat ini tentang nilai hasil pengembalian dari setiap rupiah investasi di masa yang akan datang.

Rumus nilai $\mathrm{Q}=\frac{(\mathrm{EMV}+\mathrm{D})}{(\mathrm{EBV}+\mathrm{D})}$

dengan $Q$ adalah nilai perusahaan, EMV adalah nilai pasar ekuitas, EBV nilai buku total aset dan $\mathrm{D}$ adalah nilai buku total Utang.

Analisis selanjutnya dilakukan analisisis statistik deskriptif untuk mendeskripsi hasil. Sedangkan perancangan model menggunakan SEM-PLS. Yaitu model struktural yang menghubungkan antara variabel laten yang melibatkan hubungan antara variabel independen dan dependen. Yaitu variabel kinerja Triple Bottom Line terhadap Nilai Perusahaan.

Perancangan model pengukuran dilakukan mendesain hubungan antar variabel laten yang digunakan pada penelitian ini. Model pengukuran ini mengkolerasikan variabel laten dan manifest. Penelitian ini melibatkan variabel bebas yaitu kinerja Triple Bottom Line dan Nilai Perusahaan sebagai variabel terikat. Pengujian yang dilakukan penilitian ini menggunakan SEMPLS dengan program WarpPLS 6.0. Keputusan penerimaan pengujian hipotesis untuk pengujian pengaruh secara langsung pada penelitian ini dengan menggunakan nilai $\mathrm{p}$ sebagai kriteria penerimaan atau penolakan hipotesis. Penelitian ini menetapkan signifikasi 0,05 sehingga keputusan diterima apabila nilai $p<0,05$ dan ditolak jika nilai $p>0,05$.

\section{ANALISIS DAN PEMBAHASAN}

Populasi dalam penelitian ini yaitu seluruh perusahaan manufaktur yang terdaftar di BEI tahun 2018. Pengambilan 
sampel menggunakan metode purposive sampling didasarkan beberapa kriteria tertentu yaitu: perusahaan Manufaktur Sektor Industri dasar dan kimia yang terdaftar di BEI tahun 2018. Perusahaan yang menerbitkan Annual Report atau laporan tahunan yang lengkap, perusahaan tidak mengalami kerugian pada tahun 2018 dan Laporan keuangan dinyatakan dalam rupiah.

Berdasarkan kriteria tersebut terdapat dua puluh perusahaan.

Tabel 1

Hasil Statistik Deskriptif

\begin{tabular}{lccccc}
\hline \multicolumn{1}{c}{ Indikatior } & N & Maximum & Minimum & Average & Std. Deviation \\
\hline Kinerja Ekonomi & 20 & 0,670 & 0,000 & 0,238 & 0,208 \\
Kinerja Lingkungan & 20 & 0,680 & 0,120 & 0,457 & 0,162 \\
Kinerja Sosial & 20 & 0,790 & 0,210 & 0,445 & 0,154 \\
Tobin's Q & 20 & 2,608 & 0,275 & 1,096 & 0,586 \\
\hline
\end{tabular}

(sumber: Data diolah Smart PLS3)

Berdasar tabel 1 di atas dapat diketahui kinerja ekonomi perusahaan industri dasar dan kimia dapat dikatakan masih tergolong rendah karena rata-rata hanya 0,238 atau $23,8 \%$. Perusahaan dengan kode LMSH memiliki kinerja ekonomi paling rendah dan perusahaan dengan kode WTON dan INTP memiliki kinerja ekonomi paling tinggi yaitu 0,670 . Sedangkan kinerja lingkungan sudah cukup baik yaitu rata-rata $45,7 \%$ dan kinerja sosial juga cukup baik yaitu rata-rata sebesar $44,5 \%$. Jika diamati lebih dalam kinerja lingkungn yang paling tinggi adalah perusahaan dengan kode WTON dan INCI dengan nilai 0,680 , dan perusahaan yanag memiliki kinerja lingkungan terendah adalah SULI yang hanya memiliki nilai kinerja lingkungan sebesar 0,120(12\%). Untuk kinerja sosial rata-rata cukup baik, meski ada perusahaan dengan nilai kinerja sosial paling rendah yaitu perusahaan dengan kode TRIT yaitu sebesar 0,210 dan perusahaan yang memiliki kinerja sosial paling tinggi adalah BUDI sebesar 0,790 $(79,0 \%)$. Nilai perusahaan industri dasar dan kimia pada tahun 2018 memiliki nilai perusahaan yang baik karena rata-rata nilai Tobin's Q sebesar 1,096 yang lebih besar dari pada angka satu (1) yang berarti nilai pasar aset lebih besar dari pada nilai buku aset. Namun ada perusahaan yang nilai perusahaan dengan Tobin's $Q$ dibawah 1 yaitu perusahaan dengan kode SULI hanya 0,275 ) yang berarti perusahaan tersebut tidak memiliki nilai tambah karena nilai pasar aset lebih rendah dibanding nilai buku aset. Sedangkan perusahaan yang memiliki nilai Tobin's Q terbesar yaitu perusahaan dengan kode CPIN sebesar 2,345 yang berarti perusahaan memiliki nilai pasar dua kali lipat dibanding nilai bukunya.

\section{Hasil Pengujian Model}

Hipotesis yang dirumuskan menyatakan bahwa "Triple Bottom Line berpengaruh positif terhadap nilai perusahaan". Peneliti terlebih dahulu akan menyajikan tabel kecocokan model yang menunjukan apakah data yang diuji sudah memenuhi kriteriakriteria yang ada.

Berdasarkan Tabel 1 composite reliability, cronbach alpha, AVE terhadap Nilai Perusahaan memiliki nilai 1 atau $>0,7$. Penilaian dengan VIF menunjukkan nilai sebesar 1, sehingga data penelitian dinyatakan bebas kolinearitas. Nilai adjusted $\mathrm{R}^{2}$ menunjukkan sebesar 39,9\% yang berarti nilai perusahaan dapat dijelaskan oleh variabel Triple Bottom Line sebesar 39,9\% dan sisanya sebesar $61.1 \%$ dijelaskan oleh variabel lain yang tidak dibahas dalam penelitian ini. Berdasar nilai adjusted $\mathrm{R}^{2}$ dapat dikatakan bahwa model penelitian ini termasuk moderate sebagaimana dalam (Ghozali, 2014) bahwa nilai 
batas $\mathrm{R}^{2}$ memiliki nilai batas $\leq 0.70, \leq 0.45, \leq$ 0.25 adalah kuat, moderate dan lemah. Berdasar nilai Chi-square sebesar 6.543 yang berarti Triple Bottom Line terhadap Nilai perusahaan memiliki validitas nilai prediktif $>0$ yang berarti model penelitian ini sudah terkonstruksi dengan baik.

Tabel 2

Inner Model 1

\begin{tabular}{lcc}
\hline \multicolumn{1}{c}{ Model fit } & TPL & NP \\
\hline adjusted R-square & & 0,399 \\
Composite Reliability & 0,735 & 1,000 \\
Cronbach Alpha & 0,462 & 1,000 \\
Avg. Var. Extracted & 0,486 & 1,000 \\
VIF & & 1,000 \\
Chi-squared & & 6,453 \\
\hline
\end{tabular}

Tabel 3

Inner Model 2

\begin{tabular}{lcc}
\hline \hline \multicolumn{1}{c}{ Model fit } & TPL & NP \\
\hline adjusted R-square & & 0,416 \\
Composite Reliability & 0,739 & 1,000 \\
Cronbach Alpha & 0,477 & 1,000 \\
Avg. Var. Extracted & 0,487 & 1,000 \\
VIF & & 1,000 \\
Chi-squared & & 6,068 \\
\hline
\end{tabular}

(sumber: Data diolah Smart PLS3)

Berdasarkan Tabel 3 composite reliability, cronbach alpha, AVE terhadap NP memiliki nilai 1 atau $>0,7$. Penilaian dengan VIF menunjukkan nilai sebesar 1 , sehingga data penelitian dinyatakan bebas kolinearitas. Nilai adjusted $\mathrm{R}^{2}$ menunjukkan sebesar $41,6 \%$ yang berarti nilai perusahaan dapat dijelaskan oleh variabel Triple Bottom Line sebesar $41,6 \%$ dan sisanya sebesar $58.4 \%$ dijelaskan oleh variabel lain yang tidak dibahas dalam penelitian ini. Berdasar nilai adjusted $\mathrm{R}^{2}$ dapat dikatakan bahwa model penelitian ini termasuk moderate karena nilainya terletak antara 0,25 sampai 0,45 . Berdasar nilai Chi-square sebesar 6.068 yang berarti Triple Bottom Line terhadap Nilai perusahaan memiliki validitas nilai prediktif $>0$ yang berarti model penelitian ini sudah terkonstruksi dengan baik.

\section{Pengujian Hipotesis:}

Hipotesis 1:

\section{Tabel 4}

Hasil Uji Pengaruh Triple Bottom Line pada Nilai Perusahaan

\begin{tabular}{lcc}
\hline & Coefficient & P Values \\
\cline { 2 - 3 } TP 1 -> NP & 0.656 & 0.000 \\
\hline (sumber: Data diolah Smart PLS3) & &
\end{tabular}

Kinerja Triple Bottom Line berpengaruh positif sebesar 0,656 dan siginifikan pada
Nilai Perusahaan. Koefisien menunjukkan pengaruh yang kuat dan siginifikan. Artinya 
jika kinerja Triple Bottom Line naik 1\% maka Outer Model:

Nilai Perusahaan akan naik sebesar 0,656\%

Tabel 5

Uji Pengaruh Kinerja Ekonomi, Lingkungan dan Sosial pada Triple Bottom Line

\begin{tabular}{lccc}
\hline \hline & Coefficient & t statistik & P Values \\
\hline $\mathrm{X}_{1}<-\mathrm{TP}$ & 0.575 & 1.471 & 0.127 \\
$\mathrm{X}_{2}<-\mathrm{TP}$ & 0.840 & 6.789 & 0.000 \\
$\mathrm{X}_{3}<-\mathrm{TP}$ & 0.650 & 2.194 & 0.053 \\
$\mathrm{Y}<-\mathrm{NP}$ & 1.000 & & \\
\hline
\end{tabular}

(sumber: Data diolah Smart PLS3)

Sedangkan outer modelnya menggunakan model refleksif pada Tabel $5 \mathrm{di}$ atas menunjukkan hasil bahwa Triple Bottom Line ke indikator $\mathrm{X}_{1}$ (Kinerja Ekonomi) menunjuk kan indikator Triple Bottom Line namun tidak signifikan, karena nilai thitung sebesar 1.471 dibawah $\mathrm{t}$ table $(1,96)$. Sedangkan Triple Bottom Line ke indikator $\mathrm{X}_{2}$ (Kinerja Lingkungan) menunjukkan bahwa $\mathrm{X}_{2}$ merupakan indikator Triple Bottom Line karena nilai $\mathrm{t}$ sebesar 6.789 lebih besar dari t table $(1,96)$ dan siginifikan. Demikian juga Triple Bottom Line ke indikator $\mathrm{X}_{3}$ (Kinerja sosial) menunjukkan bahwa $X_{3}$ merupakan indikator Triple Bottom Line karena nilai t sebesar 2,194 lebih besar dari $\mathrm{t}$ table $(1,96)$ dan siginifikan. Berikut gambar untuk melengkapi model tersebut:

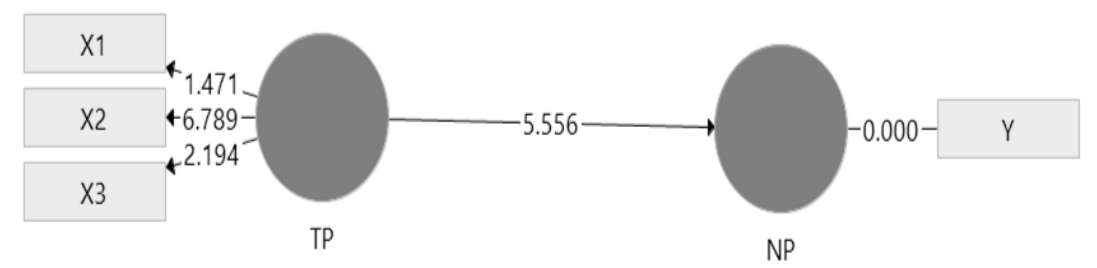

\section{Gambar 3}

Path Model 1

Dengan demikian $\mathrm{H}_{1}$ yang menyatakan kinerja Triple Bottom Line berpengaruh pada Nilai Perusahaan diterima. Berdasar gambar 3 di atas menunjukkan bahwa Triple Bottom Line berpengaruh positif secara signifikan pada Nilai Perusahaan dengan koesisen sebesar 5.556 yang artinya jika Triple Bottom Line naik 1\% maka Nilai Perusahaan juga naik sebesar 5.556\%. Bahwasanya Triple Bottom Line dibentuk oleh indikator $X_{1}$ (kinerja ekonomi) sebesar 1,47. Kemudian dibentuk oleh $\mathrm{X}_{2}$ (kinerja lingkungan) sebesar 6,79 dan oleh $\left(X_{3}\right)$ kinerja sosial sebesar 2,19.

Dapat dikatakan indikator kinerja lingkungan $\left(\mathrm{X}_{2}\right)$ berkontribusi dominan dalam membentuk Triple Bottom Line berkaitan dengan Nilai perusahaan karena memiliki koefisien paling besar daripada indikator ekonomi dan sosial.

Hipotesis 2:

Tabel 6

Hasil Uji Pengaruh Triple Bottom Line pada Nilai Perusahaan

\begin{tabular}{ccc}
\hline & Coefficient & P Values \\
\hline TP -> NP & 0.668 & 0.000 \\
\hline (sumber: Data diolah Smart PLS3) & &
\end{tabular}


Kinerja Triple Bottom Line berpengaruh positif sebesar 0,668 dan siginifikan pada Nilai Perusahaan. Kooefisien menunjukkan pengaruh yang kuat dan siginifikan. Artinya jika kinerja Triple Bottom Line naik 1\% maka Nilai Perusahaan akan naik sebesar $0,668 \%$.

Outer Model:

Tabel 7

Uji Pengaruh indikator Kinerja Ekonomi(GPM),Lingkungan dan sosial pada Triple Bottom Line

\begin{tabular}{lccc}
\hline \hline Variabel & Coefficient & t statistik & P Values \\
\hline X1 <- TP & 0.599 & 1.917 & 0.056 \\
X2 <- TP & 0.731 & 4.790 & 0.000 \\
X3 <- TP & 0.754 & 2.742 & 0.006 \\
Y <- NP & 1.000 & & \\
(sumber: Data diolah Smart PLS3) & &
\end{tabular}

Sedangkan outer modelnya menggunakan model refleksif pada Tabel 7 di atas menunjukkan hasil bahwa Triple Bottom Line ke indikator $X_{1}$ yaitu Kinerja Ekonomi yang diukur dengan Gross Profit Margin me rupakan indikator Triple Bottom Line secara signifikan, karena nilai t statistiknya sebesar 1.917 diatas $\mathrm{t}$ tabel $(1,96)$. Sedangkan Triple Bottom Line ke indikator $\mathrm{X}_{2}$ (Kinerja Lingkungan) menunjukkan bahwa $X_{2}$ merupakan indikator Triple Bottom Line karena nilai $\mathrm{t}$ statistiknya sebesar 4,790 lebih besar dari t tabel $(1,96)$ dan siginifikan. Demikian juga Triple Bottom Line ke indikator $\mathrm{X}_{3}$ (Kinerja sosial) menunjukkan bahwa $X_{3}$ merupakan indikator Triple Bottom Line karena nilai $t$ statistiknya sebesar 2,742 lebih besar dari t tabel $(1,96)$ dan siginifikan.

Berikut gambar untuk melengkapi model tersebut:

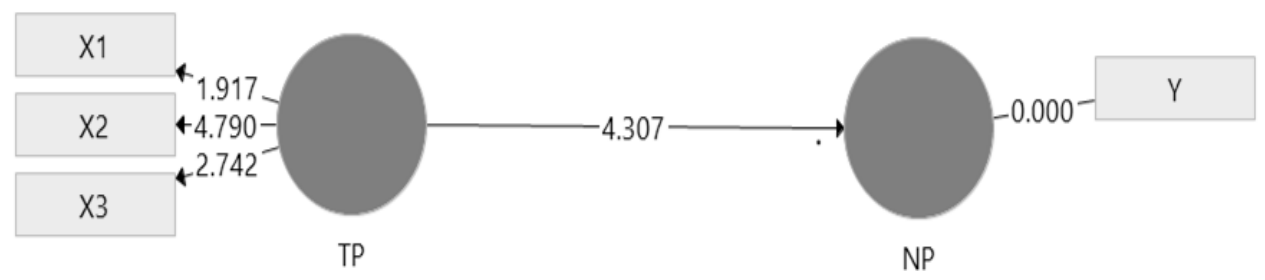

\section{Gambar 4}

Path Model 2

Dengan demikian $\mathrm{H}_{2}$ yang menyatakan Triple Bottom Line dengan indikator kinerja ekonomi yang diukur dengan Gross Profit Margin berpengaruh signifikan pada Nilai Perusahaan adalah diterima. Dapat dikatakan bahwa Triple Bottom Line berpengaruh positif secara signifikan pada Nilai perusahaan dengan koesisen sebesar 4,307 yang artinya jika Triple Bottom Line naik 1\% maka Nilai perusahaan naik sebesar $4,307 \%$. Bahwasanya Triple Bottom Line dibentuk oleh indikator $X_{1}$ (gross profit margin) sebesar 1,91. Kemudian dibentuk oleh $X_{2}$ (kinerja lingkungan) sebesar 4,79 dan oleh $\left(X_{3}\right)$ kinerja sosial sebesar 2,74. Dapat dikatakan indikator kinerja lingkungan $\left(X_{2}\right)$ berkontribusi dominan dalam membentuk Triple Bottom Line berkaitan dengan Nilai perusahaan karena memiliki koefisiesn paling besar dalam memmbentuk triple bottom line

Hipotesis 2:

Berikut disajikan tabel ringkasan pengujian Hipotesis seperti di bawah in 
Tabel 8

Ringkasan Pengujian Hipotesis:

\begin{tabular}{llllll}
\hline \hline Hipotesis & & Coefficient & t statistic & P value & Keputusan \\
\hline $\mathrm{H}_{1}$ & TP1-> NP & 0,656 & 5,556 & 0,000 & Diterima \\
$\mathrm{H}_{2}$ & TP2->NP & 0,668 & 4,307 & 0,000 & Diterima \\
\hline
\end{tabular}

(sumber: Data diolah Smart PLS3

Berdasar Tabel 8 dapat diketahui bahwa $\mathrm{H}_{1}$ dan $\mathrm{H}_{2}$ diterima yang artinya kinerja Triple Bottom Line berpengaruh pada Nilai perusahaan. Demikian juga kinerja Triple Bottom Line mengunakan indikator Gross Profit Margin untuk kinerja ekonomi berpengaruh pada nilai perusahaan dengan koefisiennya lebih tinggi dibanding jika kinerja ekonomi diukur dengan indeks pengungkapan ekonomi sesuai GRI G-4.

\section{Pembahasan}

Hasil penelitian ini memberikan bukti bahwa pengungkapan kinerja Triple Bottom Line yang tingi pada laporan tahunan akan berdampak pada peningkatkan ke- yakinan stakeholders terhadap perusahaan, sehingga stakeholders akan mengapresisasi saham perusahaan tersebut dan akan ber- dampak pada nilai perusahaan yang diukur dengan nipai pasar saham. Hasil ini terbukti pada hasil pengujian hipotesis ke-1 yang menyatakan bahwa kinerja Triple Bottom Line berpengaruh terhadap nilai perusahaan. Hal ini diperkuat dengan hasil statistik deskriptif yang menunjukkan bahwa perusahaan indutri dasar dan kimia yang terdaftar di Bursa Efek Indonesia memiliki kinerja Triple Bottom Line yang cukup tinggi terutama pada kinerja lingkungan dan sosial dengan nilai rata-rata masing-masing sebfesar 0,457 dan 0,445. Namun kinerja ekonomi perusahaan industri sandang dan kimia ini tergolong rendah karena rata-rata hanya 0,238 .

Hal ini seperti ditemukan pada pe nelitian Rocio (2018) tentang organizational logic to prioritize between the elements of triple bottom line. Hasil penelitian menunjukkan bahwa Public Hospital dan private hospital di Spanyol berbeda dalam prioritas elemen
Triple Bottom Line. Untuk Private hospital elemen paling crusial adalah indikator ekonomi. Sedangkan untuk public hospital elemen utama adalah lingkungan. Sebagaimana perusahaan industri sandang dan kimia di Indonesia lebih banyak dimiliki oleh public sehingga kinerja lingkungan dan kinerja sosial lebih tinggi dibanding kinerja ekonomi. Di Indonesia rata-rata pengungkapan CSR masih tergolong rendah sebagaimana temuan Najul (2018)tentang disclosure of corporate sustainbility performance and firm performance in Asia bahwa rata-rata level dan kualitas CSR disclosure paling tinggi adalah Jepang, kemudian Korea. Indonesia memiliki level dan kualitas paling rendah.

Dapat diketahui bahwa jika perusahaan melakukan pengelolaan dengan memperhatikan aspek ekonomi, lingkungan dan sosial secara seimbang maka akan tercipta manajemen yang kondusif sehingga investor lebih memilih berinvestasi pada saham perusahaan yang memiliki kinerja Triple Bottom Line yang tinggi. Terutama keseimbangan penggunaan sumbser daya ekonomi, lingkungan dan sosial akan berdampak pada tujuan jangka panjang atau sustainbility. Hal ini juga telah dibuktikan oleh Widhiastuti et al. (2017) tentang kinerja lingkungan yang diukur dengan CSR berpengaruh positif terhadap Return On Aset dan return saham. Demikian juga penelitian di Asia yang dilakukan oleh Najul (2018) menemukan bahwa terdapat dampak positive antara Corporate Sustainbility performance (CSP) dengan Firm Performance.

Penelitian ini mendukung penelitian yang telah dilakukan sebelumnya oleh Latifah dan Luhur (2017) bahwa rata-rata pengungkapan Sustainbility Report perusahaan go public di Indonesia pada tahun 
2016 sebesar $38 \%$ walaupun tergolong masih rendah hasil ini membuktikan bahwa pengungkapan Susatinbility Report(SR) dapat meningkatkan nilai perusahaan.

Penelitian lain yang hasilnya konsisten dengan penelitian ini telah dilakukan oleh Burhan dan Rahmanti (2012) Sampel perusahaannya adalah 32 perusahaan yang terdaftar di Bursa Efek Indonesia selama periode tahun 2006-2009. Hasil penelitian menunjukkan bahwa pelaporan berkelanjutan (Sustainbility Report) yang meliputi: pengungkapan kinerja ekonomi, pengungkapan kinerja lingkungan, dan pengungkapan kinerja sosial berpengaruh pada kinerja perusahaan yang diukur dengan Return On Asset(ROA).

Demikian juga Umbara dan Suryanawa (2014) meneliti tentang pengungkapan tanggungjawab sosial pada nilai perusahaan. Penelitian dilakukan untuk perusahaan tipe High Profile dan tipe Low Profile. Nilai perusahaan juga diukur dengan nilai Tobin's Q. Hasil penelitian menemukan bahwa CSR perusahaan high profile rata-rata hanya $11,75 \%$ dan perusahaan low profile mengungkapkan CSR rata-rata sebesar 10,40\%. Meskipun nilai pengungkapan CSR relatif rendah namun memounyai pengaruh terhadap nilai perusahaan. Hal ini juga membuktikan bahwa sesuai perusahaan yang mengungkapkan CSR lebih luas dapat menarik minat investor untuk berinvestasi pada perusahaan dengan demikian citra dan nilai perusahaan meningkat. Sesuai dengan teori stake holders: bahwa perusahaan bukan sekedar enity namun harus mampu memberikan benefit kepada semua stakeholders.

Berkaitan dengan stakeholder, perusahaan yang memiliki tingkat kinerja lingkunga yang tinggi akan direspon positif oleh stakeholder (investor) melalui fluktuasi harga saham (Robbin dan Coulter, 1999). Perusahaan mengharapkan investor akan berreaksi positif terhadap itikad baik yang dilakukan perusahaan kepada lingkungan sekitar, sehingga akan menarik minat investor untuk menginvestasikan dananya pada perusahaan. Jika minat investor naik maka akan mendorong harga saham naik. Ketika harga saham naik maka akan memberikan kemakmuran kepada para investor yang artinya meningkatkan nilai perusahaan yang tercermin pada nilai pasarnya.

Jika dihubungkan dengan teori stakeholder, perusahaan go public yang wajib melaporkan keuangannya kepada public memiliki jumlah stakeholder yang tinggi, mendapatkan pengawasan yang tinggi terhadap kegiatan operasional perusahaan dan berdampak pada pelaksanaan CSR. Sehingga diharapkan keinginan dari stakeholder dapat terakomodasi dan menghasilkan hubungan yang harmonis antara perusahaan dengan stakeholder. Seperti dijelaskan oleh Purwanto (2011) bahwa perusahaan tidak hanya dituntut untuk kepentingan perusahaan itu sendiri, melainkan juga harus memberikan manfaat bagi stakeholders nya, yaitu dengan mengungkapkan informasi yang luas sebagai upaya menjaga keberlanjutan perusahaan dan perusahaan terbebas dari resiko lingkungan maupun masyarakat.

Namun penelitian ini berbeda dengan temuan Wardoyo (2014). Penelitian tersebut dilakukan pada perbankan yang go public dan terdaftar di Bursa Efek Indonesia. Hasil peneitian menunjukkan bahwa CSR pada perbankan yang go public di Bursa Efek Indonesia pada tahun 2010 tidak mempunyai pengaruh terhadap nilai. Perusahaan.

Demikian halnya berkaitan dengan kinerja ekonomi yang diukur dengan ukuran keuangan Gross Profit Margin (GPM) juga berpengaruh pada nilai perusahaan. Gross profit margin adalah kemampuan perusahaan menghasilkan laba kotor dari penjualan. GPM juga mengukur seberapa efisien perusahaan menggunakan bahan baku, tenaga kerja langsung, dan peralatan untuk menghasilkan produk dan jasa yang akan dijual dan menghasilkan keuntungan. GPM 
ini memberikan informasi yang sebenarnya kepada investor tentang kinerja ekonomi yang sesungguhnya dari sebuah perusahaan. Berdasar uji hipotesis ke-2 dapat dibuktikan bahwa kinerja triple bottom line dengan indikator ekonomi menggunakan gross profit margin berpengaruh terhadap nilai perusahaan. Dengan demikian dapat dikatakan bahwa kinerja triple bottom line dengan ukuran indeks ekonomi sesuai GRI G-4 maupun dengan ukuran keuangan adalah sama-sama dapat mempengaruhi nilai peusahaan. Dapat dikatakan bahwa gross profit margin dapat menjadi indikator kinerja ekonomi dalam penilaian triple bottom line berkaitan dengan nilai perusahaan. Hal ini diperkuat hasil penelitian yang menunjukkan bahwa Economics Perfomance menunjukkan indeks paling tinggi dibanding environment dan social performance sehingga stakeholders lebih mementingkan kinerja ekonomi untuk menilai sebuah perusahaan (Saurabh, 2016).

Penelitian ini mendukung penelitian tentang profitabilitas, CSR dan nilai perusahaan telah dilakukan oleh Pramana dan Mustanda (2016) bahwa CSR mampu memoderasi pengaruh profitabilitas terhadap Nilai perusahaan. Penelitan ini juga memperkuat temuan Rosiana et al. (2013) bahwa profitabilitas mampu mem perkuat hubungan CSR dengan nilai perusahaan. Hal ini menjadi bukti bahwa semakin banyak informasi CSR yang diungkapkan maka akan menimbulkan kepercayaan dari stakeholder dan shareholder sehingga laba perusahaan, citra perusahaan dan harga saham meningkat. Dengan meningkatnya harga saham tersebut akan mampu meningkatkan nilai perusahaan. Jadi, semakin tinggi tingkat profitabilitas maka semakin banyak pengungkapan CSR yang dilakukan perusahaan sehingga dapat disimpulkan CSR akan meningkatkan nilai perusahaan pada saat profitabilitas meningkat. Maka kinerja ekonomi dalam Triple bottom line dapat ditambahkan sebuah ukuran keuangan yaitu gross profit margin dalam menentukan nilai perusahaan.
Temuan penelitian ini membuktikan teori stakeholders bahwa teori stakeholder mengasumsikan eksistensi perusahaan memerlukan dukungan stakeholder, sehingga aktivitas perusahaan juga mempertimbangkan persetujuan dari stakeholder. Pengungkapan sosial dan lingkungan kemudian dipandang sebagai dialog antara perusahaan dengan stakeholders (Januarti dan Apriyanti, 2005).

Sesuai dengan teori stakeholders, perusahaan wajib memenuhi hak-hak stakeho Blders untuk mendapatkan informasi yang berkaitan langsung dengan perusahaan. Laporan pertanggungjawaban sosial atau Sustainability reporting merupakan praktik pengukuran, pengungkapan, dan pertanggungjawaban kepada stakeholder internal dan eksternal perusahaan terkait dengan kinerja pencapaian tujuan keberlangsungan perusahaan (Suharno, 2017).

Sebagaimana dikemukakan oleh Januarti dan Apriyanti (2005) sesuai teori stakeholders bahwa terdapat beberapa alasan yang mendorong perusahaan perlu memperhatikan kepentingan stakeholders, yaitu: (1) Isu lingkungan melibatkan kepentingan berbagai kelompok dalam masyarakat yang dapat mengganggu kualitas hidup mereka; (2) Era globalisasi mendorong produkproduk yang diperdagangkan harus bersahabat dengan lingkungan; (3) Para investor dalam menanamkan modalnya cenderung untuk memilih perusahaan yang memiliki dan mengembangkan kebijakan dan program lingkungan; (4) LSM dan pecinta lingkungan semakin vokal dalam melakukan kritik terhadap perusahaanperusahaan yang kurang peduli terhadap lingkungan. Dengan demikian dapat dikatakan bahwa tanggung jawab sosial perusahaan bukan merupakan alat manajemen tetapi sebuah investasi jangka panjang perusahaan untuk mencapai profitabilitas dan keberlanjutan.

Bahwa profitabilitas dapat memperkuat hubungan CSR dengan nilai perusahaan juga telah diteliti oleh Sasmika dan Suprasto (2016). Ditemukan bahwa CSR perusahaan 
yang listing di BEI dengan moderasi profitabilitas berpengaruh pada nilai perusahaan. CSR berpengaruh positif terhadap nilai perusahaan dan proftibalitias mampu memperkuat pengaruh CSR terhadap nilai perusahaan.

Namun penelitian ini tidak mendukung temuan Sutriningsih et al, (2019). Penelitian dengan populasi perusahaan manufaktur yang terdaftar di BEI tahun 2015-2017. Temuan penelitian tersebut menunjukkan bahwa kinerja keuangan (ROE) tidak dapat berfungsi sebagai variabel intervening dalam pengaruh CSR terhadap nilai perusahaan pada perusahaan manufaktur di BEI periode 2015-2017. Atau dapat dikatakan bahwa profitablitias tidak dapat menjadi ukuran CSR dalam menetukan nilai perusahaan. Demikian juga hasil penelitian ini tidak mendukung temuan Lastanti dan Salim(2018) bahwa variabel pengungkapan corporate social responsibility tidak berpengaruh signifikan terhadap nilai perusahaan seluruh perusahaan manufaktur yang terdaftar di Bursa Efek Indonesia (BEI) tahun 2014-2016.

Dengan demikian penelitian ini memperkuat temuan Suartana (2010) bahwa tangung jawab sosial atau Corporate Social Responsibility perusahaan bukan merupakan alat impresi manajemen semata, tetapi merupakan investasi jangka panjang perusahaan untuk mencapai profitabilitas dan keberlanjutan perusahaan. Hasil penelitian ini memperkuat pendapat Kusniadji (2011) bahwa perusahaan perlu mengkomunikasikan Program CSR untuk Meningkatkan Citra Perusahaan. Kesuksesan Program CSR dapat memiliki dampak positif untuk meningkatkan citra perusahaan jika dilakukan secara kontinyu, terukur, dikelola dengan baik, berorientasi internal dan eksternal.

Triple Bottom Line merupakan tujuan jangka panjang sebuah perusahaan atau tujuan keberlangsungan usaha. Hasil penelitian ini memperkuat penelitian tentang penilaian perusahaan berdasar faktor keuangan dan non keuangan. Faktor non keuangan lain selain triple bottom line adalah green accounting. Sebagaimana penelitian berkaitan dengan green accounting dengan tujuan keberlangsungan usaha. Hasil penelitian tersebut membuktikan bahwa green accounting dapat memoderasi hasil atau nilai produksi terhadap keberlangsungan usaha. Hal ini bukti bahwa nilai perusahaan dapat diukur dengan faktor keuangan dan faktor non keuangan.

\section{SIMPULAN DAN SARAN}

Berdasar hasil analisis data berkaitan dengan kinerja triple bottom line dan nilai perusahaan pada perusahaan manufaktur sektor industri dasar dan kimia, dapat disimpulkan bahwa kinerja triple bottom line dengan indikator kinerja ekonomi, lingkungan dan sosial berpengaruh positif dan signifikan terhadap nilai perusahaan yang diukur dengan nilai pasar perusahaan yang diukur dengan nilai pasar Tobin's Q. Demikian juga jika indikator ekonomi diukur dengan ukuran keuangan berupa profitabilitas yaitu gross profit margin maka kinerja triple bottom line berpengaruh posistif dan signifikan pada nilai perusahaan berdasar nilai pasar Tobin's Q. Sehingga gross profit margin dapat menjadi ukuran pada indikator kinerja ekonomi berkaitan dengan nilai perusahaan.

Untuk itu dalam penilaian kinerja berdasar pendekatan triple bottom line dapat menentuan nilai perusahaan menggunakan indikator ekonomi, indikator lingkungan dan indikator sosial. Disamping itu indikator keuangan berdasar profitabilitas yaitu gross profit margin dapat menjadi tambahan indikator kinerja ekonomi pada triple bottom line untuk menentukan nilai perusahaan. Keterbatasan penelitian ini hanya dilakukan pada perusahaan yang bergerak pada industri dasar dan kimia yang terdaftar di Bursa Efek Indonesia pada tahun 2018 dengan jumlah sampel yang terbatas sehingga belum bisa menggambarkan secara detail tentang kinerja Triple Bottom Line perusahaan di Indonesia. Peneliti selanjut- 
nya dapat memperbanyak sampel penelitian tidak membatasi scope industri tertentu atau memperpanjang periode pengamatan sehingga dapat memperoleh hasil yang lebih baik.

Kontribusi penelitian ini berguna untuk menjadi model alternatif dalam mengukur nilai perusahaan. Bahwa nilai perusahaan yang diukur dengan nilai pasar Tobin's $Q$ dapat ditentukan berdasar pelaporan Triple Bottom line yang telah dilaporan dalam pelaporan Corporate Social Responsibilty perusahaan. Temuan lain yang menjadi kebaruan penelitian ini adalah bahwa kinerja keuangan yang diukur dengan profitabilitas berupa gross profit margin dapat menjadi indikator ekonomi dalam triple bottom line untuk membentuk nilai perusahaan. Dengan demikian sebaiknya stakeholders menilai kinerja perusahaan dapat menggabungkan faktor keuangan seperti profitabilitas dengan kinerja non keuangan yang meliputi kinerja perusahaan dalam mengelola ekonomi, planet dan people atau yang dikenal dengan triple bottom line.

Informasi ini berguna untuk para stakeholders dalam pengambilan keputusan. Seperti investor dalam mengambil keputusan investasi hendaknya tidak hanya mempertimbangkan faktor keuangan saja namun perlu mempertimbangkan faktor kinerja triple bottom line atau CSR sebuah perusahaan. Demikian juga pihak manajemen dapat meningkatkan nilai perusahaan berdasar kinerja ekonomi, kinerja lingkungan dan kinerja sosial. Disamping keharusan memenuhi peraturan atau Undangundang terbukti secara empiris dapat meningkatkan nilai perusahaan.

\section{DAFTAR PUSTAKA}

Agustine, I. 2014. Pengaruh Corporate Social Responsibility Terhadap Nilai Perusahaan. Finesta 2(1): 42-47.

Anindita, M. Y. K. P. 2014. Pengaruh Ukuran Perusahaan, Profitabilitas dan tipe Industri Terhadap Pengungkapan Sukarela Pelaporan Keberlanjutan. Jurnal
Fakultas Ekonomi Universitas Atma Jaya Yogyakarta: 1-15.

Astuti, H. H., R. A. Oktavianu, dan Y. Augustin. 2018. Pengaruh Pengungkapan Corporate Social Responsibility Dan Kinerja Terhadap Nilai Perusahaan Dengan Tipe Industri Sebagai Variabel Moderasi. Jurnal Magister Akuntansi Trisakti 5(2): 185-202.

Aulia, S. Z. dan Kartawijaya. 2011. Analisis Pengungkapan Triple Bottom Line dan Faktor yang mempengaruhi: Lintas Negara Indonesia dan Jepang. Simposium Nasional Akuntansi XIV Aceh.

Brigham, E. F. dan J. F. Houston. 2010. Dasardasar Manajemen Keuangan. Salemba Empat. Jakarta.

Dahlia dan Siregar. 2008. Pengaruh CSR terhadap kinerja Perusahaan (Studi Pada Perusahaan di BEI tahun 2005 dan 2006). Simposium Nasional Akuntansi IX Padang 23-26 Agustus 2006.

Dean, K. L. 1998. The chicken and the egg revisited: Ties between corporate social performance and the financial bottom line. The Academy of Management Executive 12(2): 99-100.

Devi, S., I. G. N. Budiasih, dan I. D. N. Badera. 2017. Pengaruh Pengungkapan Enterprise Risk Management dan Pengungkapan Intellectual Capital Terhadap Nilai Perusahaan. Jurnal Akuntansi dan Keuangan Indonesia 14(1): 20-45.

Eduardus, E. dan Juniarti. 2016. Kinerja Sosial Perusahaan Dan Kinerja Keuangan Perusahaan Yang Diukur Menggunakan Tobin's Q. Business Accounting Review 4(1): 517-528.

Ghozali, I. 2014. Konsep dan Aplikasi Dengan Program AMOS 22.0 Update Bayesian SEM (Vol. 6). Badan Penerbit Universitas Diponegoro. Semarang.

Gusaptono, R. H. 2010. Faktor-Faktor Yang Mendorong Penciptaan Nilai Perusahaan di BEI. Buletin Ekonomi 8(2): 149-158.

Haposro, D. 2009. Pengaruh Transparansi Terhadap Nilai Perusahaan: Studi 
Empiris di Pasar Modal Indonesia. Jurnal Akuntansi dan Manjemen 20(1): 1324.

Harjito, A. dan S. Martono. 2005. Manajemen Keuangan. Penerbit Ekonisia Kampus Fakultas Ekonomi UII. Yogyakarta.

Husnan, A. dan S. Pamudji. 2013. Pengaruh Corporate Social Responsibility (CSR Disclosure) Terhadap Kinerja Keuangan Perusahaan. Diponegoro Journal of Accounting 2(2): 1-8.

Jackson, A., K. Boswell, dan D. Davis. 2011. Sustainability and Triple Bottom Line Reporting-What is It all About? International Business, Humanities and Technology 1(3): 55-59.

Januarti, I. dan D. Apriyanti. 2005. Pengaruh Tanggung Jawab Sosial Perusahaan terhadap Kinerja Keuangan. Jurnal Manajemen, Akuntansi dan Sistem Informasi Semarang 5: 227-243.

Kusniadji, S. 2011. Mengkomunikasikan Program CSR untuk Meningkatkan Citra Perusahaan. Jurnal Komunikasi Universitas Tarumanegara 3(01).

Laksmitaningrum, C. F. dan A. Purwanto. 2013. Analisis Pengaruh Karakteristik Perusahaan, Ukuran Dewan Komisaris dan Struktur Kepemilikan Terhadap Pengungkapan CSR (Studi Empiris pada Perusahaan Manufaktur yang Terdaftar di Bursa Efek Indonesia Tahun 20092011). Diponegoro Journal of Accounting 2(3): 1-10.

Lang, L., R. Stuitz, dan Walking. 1989. Managerial Performance, Tobin's q and The Gains from Successfull Tender Offers. Jounal of Financial Economics 102: 1248-1280.

Lastanti, H. S. dan N. Salim. 2018. Pengaruh Pengungkapan Corporate Social Responsibility, Good Corporate Governance, dan Kinerja Keuangan Terhadap Nilai Perusahaan. Jurnal Akuntansi Trisakti 5(1): 27-40.

Latifah, S. W. 2012. Pengaruh CSR Berbasis ISO 26000 Terhadap Nilai Perusahaan dengan Karakteristik Perusahaan
Sebagai Variabel Moderating. Jurnal Humanity 7(2): 98-110.

Latifah, S. W. 2016. Sustainability Report, Tinjauan Sekilas! Ekuitas: Majalah Mahasiswa Akuntansi 9.

Latifah, S. W. dan M. B. Luhur. 2017. Disclosure of Sustainability Report and Moderating of Profitability and Its Impact on Firm Value. Journal of Accounting and Business UNS 17(1).

Mutammimah. 2020. Faktor-Faktor yang Mempengaruhi Nilai Perusahaan (Studi Empiris pada Perusahaan Manufaktur yang Terdaftar di BEI tahun 2013-2017). Maksimum Media Akuntansi Universitas Muhammadiyah Semarang 10(1): 64-84.

Najul, L. 2018. Disclosure of corporate sustainability performance and firm performance in Asia. Asian Review of Accounting 26(4): 414-443.

Burhan, A. H. N. dan W. Rahmanti. 2012. The Impact of Sustainability Reporting on Company Performance. Journal of Economics, Business, and Accountancy Ventura, 15(2): 257-272.

Nurfajriyah. 2011. Implementasi Konsep Triple Bottom Line pada PT. Pertamina (Pesero). Tesis. UIN Sunan Kalijaga. Depok.

Nurlela dan Islahudin. 2007. Pengaruh CSR terhadap Nilai Perusahaan dengan Prosentase kepemilikan sebagai variabel Moderating (Studi pada Perusahaan di BEI). Simposium Nasional Akuntansi XI Pontianak.

Pramana, I. G. N. A. D. dan I. K. Mustanda. 2016. Pengaruh Profitabilitas dan Size Terhadap Nilai Perusahaan dengan CSR sebagai Variabel Pemoderasi. E-Jurnal Manajemen Unud 5(1): 561-594.

Purwanto, A. 2011. Pengaruh Tipe Industri, Ukuran Perusahaan, Profitabilitas, Terhadap Corporate Social Responsibility. Jurnal Akuntansi \& Auditing 8(1): 12-29.

Putri, R. S. F., P. D. Paramita, dan H. Hartono. 2018. Faktor-Faktor Yang Berpengaruh Terhadap Nilai Perusahaan Dengan Kinerja Keuangan Perusahaan 
Sebagai Variabel Intervening (Case Study at Manufacturing Companies Industry Basic Chemistry and the period 2011-2015. Journal of Accounting 4(4).

Raharjo, A. dan I. Djanuarti. 2014. Pengaruh Tanggungjawab Sosial Perusahaan terhadap Nilai perusahaan Studi Kasus pada Perusahaan Pertambangan Yang Terdaftar di BEI 2008-2012. Diponegoro Journal of Accounting 3(1): 1-10.

Rahayu, M. dan B. Sari. 2018. Faktor-faktor yang Mempengaruhi Nilai Perusahaan. IKRA-ITH HUMANIORA: Jurnal Sosial dan Humaniora 2(2): 69-76.

Robbin, S. P. dan M. Coulter. 1999. Management. Prentice-Hall International. New Jersey.

Rocio, R. 2018. Organizational Logic to Prioritize between the Elements of Triple Bottom Line. Benchmarking: An International Journal 25(6): 1626-1640.

Rosiana, G. A. M. E., G. Juliarsa, dan M. M. R. Sari. 2013. Pengaruh Pengungkapan CSR terhadap Nilai Perusahaan dengan Profitabilitas sebagai Variabel Pemoderasi. E-Jurnal Akuntansi Universitas Udayana 5(3): 723-738.

Ross, S. A., R. W. Westerfield, B. D. Jordan, J. Lim, dan R. Tan. 2015. Fundamentals of Corporate Finance (Edisi Global Asia). Penerbit Salemba Empat. Jakarta.

Sasmika, I. A. dan B. Suprasto. 2016. Pengaruh Tanggung Jawab Sosial Perusahaan Dan Mekanisme Tata Kelola Perusahaan Terhadap Nilai Perusahaan. E-Jurnal Akuntansi Universitas Udayana 15(1): 667-694.

Saurabh, A. 2016. Triple bottom line performance evaluation of reverse logistics. Competitiveness Review 26(3): 289-310.

Schadewitz, H. J. dan M. Niskala. 2020. Communication via responsibility reporting and its effect on firm value in Finland. Corporate Responsibility and Environmental Managemenet 12(2).

Septariani, D. 2017. Pengaruh kebijakan dividen dan kebijakan hutang terhadap nilai perusahaan (Studi Empiris Pada Perusahaan LQ45 di BEI Periode 2012-
2015). JABE (Journal of Applied Business and Economic) 3(3): 183-195.

Suartana, I. W. 2010. Akuntansi Lingkungan dan Triple Bottom Line Accounting: Paradigma Baru Akuntansi Bernilai Tambah. Bumi Lestari Journal of Environment 10(1): 108-112.

Suharno, P. 2017. The effect of work environment, leadership style, and organizational culture towards job satisfaction and its implication towards employee performance in Parador Hotels and Resorts, Indonesia. International Journal of Law and Management 59(6): 1337-1358.

Sutriningsih, L. Handajani, dan A. Rifa'i. 2019. Kinerja Keuangan Memediasi Pengaruh Corporate Social Responsibility dan Struktur Modal Terhadap Nilai Perusahaan. E-Jurnal Akuntansi Universitas Udayana 27(1): 764-791.

Umbara, D. M. B. dan I. K. Suryanawa. 2014. Pengaruh Pengungkapan Tanggung Jawab Sosial Pada Nilai Perusahaan. EJurnal Akuntansi 9(2): 410-424.

Utari, M. D. 2014. Analisis Pengaruh Kriteria Good Corporate Governance Terhadap Pengungkapan Corporate Social Responsibility Pada Perusahaan SubSektor Farmasi Yang Terdaftar Di Bursa Efek. Jurnal Audit dan Akuntansi Fakultas Ekonomi 3(1).

Waddock, S. A. dan S. B. Graves. 1997. The Corporate Social Performance-Financial Performance. Strategic Management Journal 18(4): 303-319.

Wardoyo, W. A. 2014. Pengaruh Kinerja Keuangan dan Corporate Social Responsibility terhadap Nilai Perusahaan pada Bank Go Public yang Terdaftar di Bursa Efek Indonesia. BENEFIT Jurnal Manajemen dan Bisnis 18(1): 57-66.

Widhiastuti, N. L. P., I. D. G. Saputra, dan I. G. A. N. Budiasih. 2017. Pengaruh Kinerja Lingkungan pada Kinerja Keuangan dengan Corporate Social Responsibility sebagai Variabel Intervening. E-Jurnal Ekonomi dan Bisnis Universitas Udayana 6(2): 819-846. 
Yapto, M., K. D. Frisko, dan Rizki. 2013. Pengaruh Tanggung jawab Sosial Perusahaan Terhadap Nilai Perusahaan Studi Kasus pada Perusahaan Manufaktur yang Terdaftar di BEI periode 2010-2011. Calyptra Jurnal 2(1).
EBRD. 2014. European Bank for Rescontruction and Development. EBRD Environment and Social Risk Categorisation List. http://www.adb.org/sites/ default/files/linked-documents/45230-001arm-esms.pdf. 